\title{
Individual Approach in Improving the Compliance of the Learning Process of Children With Special Needs in Autism in SLB Asuhan Kasih, Kupang City
}

\author{
Abdul Syahril Muh ${ }^{1 *}$, Megawati MBK ${ }^{2}$ \\ ${ }^{1,2}$ Department of Elementary Teacher Education, Universitas Muhammadiyah Kupang, Jl. K. H. Ahmad Dahlan, \\ Kayu Putih, Kupang city, East Nusa Tenggara \\ *Corresponding author, Email :syahrilabdul45@gmail.com
}

\begin{abstract}
Children with autism have severe developmental disorders or neurobiological factors that are widespread and can occur in children in the first three years of life. An individual approach can be used by the teacher as a solution to improve the compliance of learning processes for students with autism in the classroom. This study aimed to find out the implementation of individual approach in the learning process for children with autism and to find out whether an individual approach can improve the compliance of learning process for children with autism. This study used a qualitative approach. Data collection techniques used were interviews, observation, and documentation. The data collected were analyzed using data reduction, data presentation, and drawing conclusions on the results of the study. The results of this study show that there was improvement in the level of compliance of learning processes for children with autism in SLB Asuhan Kasih, Kupang City. Therefore, it can be concluded that individual approach can be implemented since it affected significantly on the level of compliance of the learning process for children with autism in SLB Asuhan Kasih, Kupang City.
\end{abstract}

Keywords: Induvidual Approach, Autistic, Improving the Compliance

\section{INTRODUCTION}

Education is the right of every citizen, without exceptions. Education is a place for each individual in the teaching and learning processes to develop $I Q$, skill, and the potential within individual. In addition, education is a very important element in creating quality, intelligent, peaceful, open, democratic and competitive resources and can improve the welfare of all Indonesian citizens. The purpose of education is intended for all Indonesian citizens, including children with disabilities or special needs.

In this case, education is very important for human life, so education is not specifically for those who are physically fit but children with special needs who have physical, mental, and other problems are also entitled to get proper education. Therefore, educational programs should always be reviewed and improved, one of which, the approach to be used by a teacher must be adapted to the situation of students who experience limitations, i.e. an individual approach.

An individual approach pays attention to individual factors as a whole including character, intelligence, psychology, and psychomotor abilities (M. Widda Djuhan, 2013) [1].The individual approach is carried out directly by a teacher to the students to solve their problems. The individual approach also serves individual student differences in such a way that its application enables the development of the potential of each student to participate in the learning process in the classroom optimally.

Suryadinata \& Farida (2016) [2] stated that children with special needs are children with different special characteristics in general without always showing mental, emotional, or physical disabilities. Children with special needs have different characteristics according to the disorder they have (Lestari, 2015) [3].Some of developmental barriers and deviations in children with special needs are often known as visually impaired, deaf, mentally retarded, disabled, slow learning, gifted, emotion and social disorders, ADHD, and autism (Nida, 2013) [4].

Autism is a severe developmental disorder or neurobiological factor that is widespread and can occur in children in the first three years of life (Saad, 2018) [5]. According to Yuwono (2012)[6], autism is a disorder about how children see the world and how they learn through their experiences. Children with autistic disorders are usually less able to feel social contact (Mazurek, 2017)[7]. People are 
considered as objects instead of subjects who can interact and communicate (Nurdiansyah, 2014) [8].

One of the assistances for children with autism about obedience comes from the word "obedient" which means obey, willing to obey, or discipline. Obedience, according to Simamora (2012) [9], is the level of behavior in taking an action command, for example in sitting, standing, looking, opening instructions, etc. This usually happens to children with special needs in general.

Autism symptoms appear before the age of 3 years (Baio, 2018) [10]. Children with autism in terms of their appearance/events can occur from birth which is called classic autism and after birth where children up to 1-2 years of age show normal development. However, the next period shows a downward/backward development. This is called autistic regression (Strang, 2018) [11].

Based on the results of preliminary observations on the SLB Asuhan Kasih in Kupang City, the problem faced by teachers in providing learning is the lack of concentration of learning in children with autism which is natural for them. One of the teachers at SLB Asuhan Kasih explained that the most difficult thing faced by them was the lack of focus on children with autism and selfishness. This can also be seen from the obedience of an autistic student in participating in learning is still lacking. Therefore, an individual approach can be used to measure the obedience of an autistic student in the learning process.

Besides, the lack of infrastructure and classrooms has made the learning process of autistic children is in the same class with children who have other disorders such as mentally disabled. Another obstacle found in SLB Ausah Kasih is the number of classy autistic students there are only one to three children. This problem greatly affects the learning process in measuring student obedience when they do not attend the class which is affected by the disorder experienced by children with autism. For assessment, the teachers have not been able to determine the Minimum Mastery Criteria score and also the value of the attitude of student obedience because it is seen from the condition of autistic students, i.e. lack of concentration and more selfish.

\section{RESEARCH METHODOLOGY}

\subsection{Research Location and Time}

This research was conducted in SLB Asuhan Kasih in Kupang City in the Academic Year of 2019/2020 from March to April 2020.

\subsection{Type of research}

The type of research used is descriptive qualitative research. Descriptive qualitative research is a type of research that seeks to describe the object or subject being studied in accordance with what it is to systematically describe the facts and characteristics of the object being studied appropriately (Misna, 2015) [12].

In addition, this approach also aims to gain a deep and natural understanding and interpretation of the meaning of phenomena in the field. In accordance with the chosen research method, this study did not depart from a hypothesis to be tested for its validity or suitability in the field. Instead, it did the research directly into the field and tried to collect data as completely as possible in accordance with the subject matter being investigated (Maartiyanti \& Budi, 2017) [13].

\subsection{Research Subjects}

Research subjects or respondents are people who are asked to provide information about a fact or opinion. The research subjects are used to determine who will be examined as respondents. The main data sources in this study are words and actions, as well as additional data such as documents, etc. (Moleong, 2009) [14]. The research subjects were teaching staff in SLB Asuhan Kasih, Kupang.

\subsection{Data Type and Data Source}

The data used in this study is qualitative. Qualitative data are presented in the form of verbal words instead of numbers. Included in the qualitative data in this study are a general description of the object of research, including the state of the teacher, the condition of students, facilities and infrastructure in applying an individual approach to increasing the obedience of students with autistic children.

Data sources in research are subjects from which data can be obtained. In this study, the authors used two data sources, namely:

a. primary data sources, i.e. data that is directly collected by the researcher (or officer) from the first source. In this study, the primary data were taken from the class teacher of deaf students.

b. Secondary data sources are data directly collected by researchers as a support from the first source. It can also be said that the data are arranged in the form of documents. In this research, the secondary data source was documentation.

\subsection{Data Collection Technique}

a. Interview

An interview is a conversation with a specific purpose. The conversation was carried out by two parties, namely the interviewer that asks questions and is interviewee which provides answers to the questions (Moleong, 2010) [15]. Interview technique in this research is structured interview, i.e. interviews are conducted using 
several questions systematically and the questions raised have been compiled.

b. Observation

The researcher chose the type of participatory observation that is observation which at the same time engages as a person in certain situations. This was to make it easier for researchers to obtain data or information easily and freely.

c. Documentation

According to Sudaryono (2016) [16], documentation is shown to obtain data directly from the research site, including relevant books, regulations, activity reports, photographs, documentary films, relevant data on research. Documentation can take the form of writing, for example diaries, life history, stories, biographies, regulations and policies. Documents in the form of pictures can be photos, living drawings, sketches, etc.

\subsection{Data analysis technique}

Sugiyono (2016) [17] said that data analysis is the process of systematically searching and compiling data obtained from interviews, field notes and documentation, by organizing data into categories, breaking down into units, synthesizing, compiling to in patterns, choose what is important and what will be learned, and make conclusions so that it is easily understood by oneself and others. The data analysis technique used in this study was the data analysis technique in the field proposed by Miles and Hubberman. It is also called interactive data analysis technique where the data analysis is carried out interactively and continuously until it is complete or saturated.

Chart 2. The Interactive Analysis Model of Miles and Hubberman

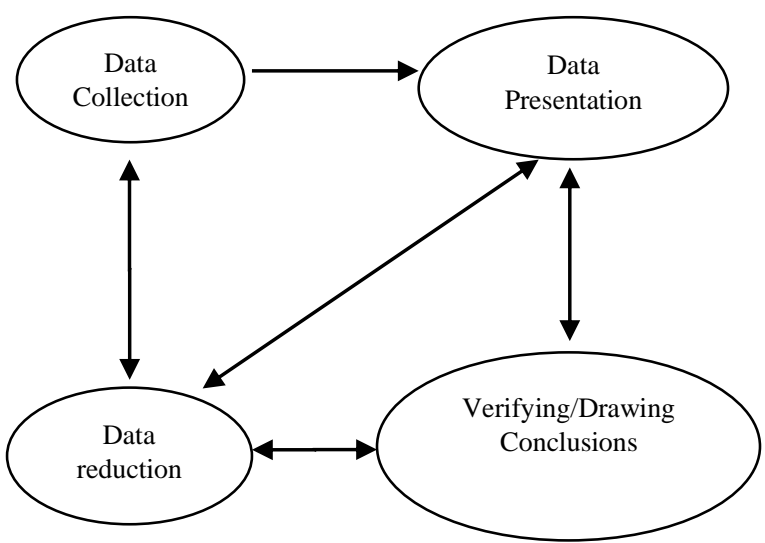

\section{RESEARCH RESULT}

3.1 Description of Research Results

Based on research in the field from interviews and observations, the researchers found several findings related to the use of approaches in improving the obedience of the learning process in autistic students.

The first question is "What is the learning approach that teachers do for autistic students during the learning process?"

"Our learning processes use media such as balls or colorful pictures to practice focus while learning is taking place. We must be patient in facing their attitudes since autistic students are still combined with other students".

Based on the statement above, it can be concluded that the learning process of autistic students must use the media in order to train the level of autism students' focus when the learning process is ongoing. A teacher is also patient in dealing with autistic students with various disabilities in the classroom.

Second question, "Has the individual approach been applied earlier or has it only been applied in the learning process in the Academic Year of 2019/2020?"

We have just applied new individual approach to children with autism because the formation of autistic students in an individual way can affect their attitude obedience.

New individual approach is applied to autistic students. The individual approach is a direct approach taken by teachers to their students to solve the problems experienced by these students. Therefore, the individual approach is very appropriate to be applied to autistic students.

Third Question, "What problems are faced in teaching autistic children in class?"

"In the classroom, there are not only autistic students but there are some other students such as mild, moderate and severe mentally disabled. Thus, we find it difficult in dealing with both autistic and mentally disabled children because they have different disabilities."

The problem faced by teachers in teaching autistic students is that special classes for autistic students are not yet available. This makes the teachers find it difficult in dealing with autistic students in the classroom. Special classes are very helpful for autistic children in the process of individual approaches in achieving student obedience. In SLB Asuhan Kasih, there is some constraints related to class infrastructure. 
Fourth Question, "Can an individual approach increase autism student obedience?"

"It has an effect, because we use a very good individual approach and we adapt it to their emotional states that are temporary (good and bad moods)."

In accordance with the statement above, it can be concluded that the individual approach can affect the learning process carried out for autistic students because the individual approach is very appropriate to be applied to autistic students. An individual approach to children with autism means that directly a teacher can master the students personally in the process of solving problems experienced by these students.

Fifth Question, "In your opinion, is it important to build obedience with autistic students using an individual approach?"

"It is very important, because they must follow what we submit so that the material delivered to them can be well received by autistic students. If their obedience is low, the material delivered will not be accepted by autistic students."

Building autism students' obedience is very urgent in the process of handling autistic children, because obedience is the main thing desired by teachers in schools and students' parents. The teacher really expects autistic students to be obedient in following all the rules in school so that the learning process can run well. Obedience is very important in autistic students because autistic children have a disability that is different from other disabilities. In this case, an autistic child has a higher emotional level than other disabilities.

Sixth Question, "What is the grading system for autistic students?"

"Before the K13 assessment was applied, the general assessment system was still used. When using K13, the assessment was seen from the level of obedience of autistic students both in recognition of numbers, letters, and the level of obedience with teachers."

The assessment system for learning processes of autistic children in SLB Asuhan Kasih is a K13 assessment system that is simplified so that autistic students can accept the learning given by the teacher. The most important assessment of autistic students is obedience assessment which is the main assessment of autistic students. The concept of obedience assessment expected by autistic children guidance teachers is the change in behavior of autistic children from bad to better in terms of the daily changes of students at school and at home both in behavior and verbal.

Seventh question, "Can all children with autism who are combined be approached individually?"
"Yes, because autistic children have different characteristics from other children, so the individual approach is very appropriate to deal with autistic children in the classroom."

Although autistic students are combined with other disabilities, an individual approach can be taken for autistic students. In this case, the individual approach is very appropriate to deal with autistic children and other disabilities because the teacher can control each student both autistic students and other disabilities individually.

Autistic students' obedience has increased, even though it is adjusted to the emotional level of an autistic child. In general, autistic students have emotional levels that cannot be controlled so it is very difficult to deal with autistic students. The individual approach is very influential on the obedience of autistic students who have experienced significant changes.

The use of individual approaches to improve adherence to new autistic students is applied in the learning process in the classroom. The individual approach is very influential on the attitudes of autistic students' obedience because it can be seen from the changing attitudes of students who have begun to obey in following the teacher's instructions. Provision of material per individual conducted by class teachers has gained a significant influence in the learning process in class.

\subsection{Results of Data Analysis}

In this study, researchers focused on the attitude of autism students' obedience by using an individual approach in the learning process. The following is an overview of how to teach Ms. Sela in the classroom

a. The learning processes use an individual approach in increasing the obedience of autistic students in class I SDLB Asuhan Kasih.

The subject of the teacher who is very patient, enthusiastic and intelligent in dealing with autistic children in the learning process is related to forming the attitude of obedience of autistic children in the classroom. In the process of learning in the classroom, teachers more often approach each individual student with autism by providing various objects that can affect autistic students so that they are able to accept the material presented.

In the learning process, the teacher applies an individual approach to measure changes in obedience attitudes, because autistic students must have an obedient attitude first so that they can receive any material given properly. Autistic students are usually given colored objects to increase their focus, the teacher also gives an assignment in the form of asking autistic 
students to write in front of the class to train autistic students mentally.

The new individual approach applied to autistic students is very influential on changes in the attitude of autistic students in improving obedience during the learning process. The way teachers approach individual students is also so good that it makes them feel comfortable accepting any material that has been simplified to be accepted by autistic students.

b. Benefit from the influence of using an individual approach to improve autism student obedience during the learning process.

The benefits felt by the subject, in this case the autistic class teacher, is in increasing obedience by using an individual approach experienced very good changes. It can assist students in increasing the focus of autistic students, the attitude of obedience of autistic students begins to increase. So that the learning process in class can run according to the shared goals and the material provided they can receive well.

\section{DISCUSSIONS}

Discussion of the results of this study focuses on findings that can improve the attitude of obedience for autistic students. This case study research aims to explain the effect of using an individual approach to improve obedience in the learning process of autistic students. This individual approach can give effect to the level of obedience so that autistic students can accept learning calmly and well. The individual approach can help the teacher in providing learning material after this autistic student's obedience attitude is formed using an individual approach.

The learning process carried out by SLB teachers towards autistic students is quite simple so that autistic students are able to receive material well. The curriculum applied to autistic students, namely $\mathrm{K} 13$, is simplified so that autistic students can receive every material given. The material provided by the teacher uses picture media as well as colored objects so as to train the degree of autism students' focus. In this way, the level of obedience of autistic students will be seen and the teacher takes an individual approach to each autistic student so that the obedient attitude in following the learning goes well.

It can also be helpful in the learning process, in which autistic students become more focused and obedient in following the learning process. Astutik (2010) [18] stated that the Lovaas/Applied Behavior Analysis (ABA) Method is a method that teaches discipline whose curriculum has been modified from daily activities and implemented consistently to improve disciplinary behavior with an individual approach to increase obedience obedience for autistic students in SLB. The results of this study show that the formation of autism student obedience using this individual approach has to do with the ABA method, which considers several things, namely:

1. Obedience and eye contact

2. One one one, namely teaching individually

3. Cycle and Discrete Trial Training, which is a behavioral analysis technique to improve skills in children with autism that starts with instructions and ends with rewards.

4. Fading systematic reduction of assistance. This reduction is very important so that the child does not depend on help and cues.

5. Shaping, procedures used to develop skills or behavior that are not present in a person.

The implementation of the research faced problems, namely the research process was carried out in the middle of the Covid-19 pandemic, thus preventing researchers from conducting more indepth interviews of the subjects. The study was conducted using qualitative methods obtained through in-depth interviews.

But from the constraints experienced above, it can be said that this is a drawback of the research that the authors carried out. However, this research can at least serve as a temporary conclusion, because this can be re-tested elsewhere and with other results as well.

\section{CONCLUSIONS}

From the results of this study, the authors conclude as follows:

1. The individual approach adopted at the SLB Asuhan Kasih greatly influenced the obedience of autistic students. The learning process was carried out by providing learning material individually for each autistic child in grade 1 elementary school. Obedience is a benchmark for children with special needs with autism so that the individual approach is very appropriate to be used in the learning process in autistic students.

2. Individual Approach in Improving the Obedience of the Learning Process of Children with Special Needs in Autism in SLB Asuhan Kasih, Kupang City The results of an interview with one of the teachers in the autistic class show that before the individual approach was applied to autistic students, the level of autism students' obedience was low. Meanwhile, after applying the individual approach to the autistic class, the level of autism student obedience experienced a significant increase in the learning process in the classroom. 


\section{SUGGESTIONS}

Through this research, the authors would like to convey the following suggestions:

1. For SLB Asuhan Kasih

SLB Asuhan Kasih can provide additional special class for children with autism so that the leraning process can be conducted more effectively. The teachers of SLB Asuhan Kasih are hoped to be more creative and professional in the learning process in using individual approach to increase the the learning goals. The teacher able to give a good stimulant to children with autism so the compliance level can be well developed.

2. For For the next researcher

For the next researcher is hoped to study more sources and references in the novelty of knowledge on individual approach research in increasing student with autism's compliance so that the research can be better and have a new knowledge.

\section{REFERENCES}

[1] M. Widda Djuhan. (2013). Sosiologi Pendidikan,(Pendekatan individual). STAIN Ponorogo

[2] Suryadinata \& Farida. (Geniofam, 2016). Journal of Disability Studies (Vol. V, No. 2, July December 2018)

[3] Lestari. (2015). Journal of Disability Studies (Vol. V, No. 2, July - December 2018)

[4] Nida. (2013). Journal of Disability Studies (Vol. V, No. 2, July - December 2018)

[5] Saad. (2018). Journal of Disability Studies (Vol. V, No. 2, July - December 2018).

[6] Joko Yuwono (2012). Memahami Anak Autis. Bandung. Alfabeta

[7] Mazurek. (2017). Journal of Disability Studies (Vol. V, No. 2, July - December 2018)

[8] Nurdiansyah. (2014). Journal of Disability Studies (Vol. V, No. 2, July - December 2018).

[9] Simamora. J.(2012). Faktor yang Mempengaruhi Ketidakteraturan Berobat Penderita TB. Medan. USU

[10] Baio. (2018). Journal of Disability Studies (Vol. V, No. 2, July-December 2018)

[11] Strang. (2018). Journal of Disability Studies (Vol. V, No. 2, July - December 2018).

[12] Misna. (2015). Journal of Disability Studies (Vol. V, No. 2, July - December 2018)

[13] Maartiyanti \& Budi. (2017). Journal of Disability Studies (Vol. V, No. 2, July - December 2018)
[14] Moleong, Lexy J. 2009. Metodologi Penelitian Kualitatif. Bandung: PT Remaja Rosda Karya

[15] Moleong, Lexy J. 2010. Metodologi Penelitian Kualitatif, Bandung: Remaja Rosda karya.

[16] Sudaryono. (2016). Pembelajaran pendidikan agama islam pada anak autis disekolah luar biasa Negeri Wonogiri, Tahun ajaran 2017/2018.

[17] Sugiyono. (2016). Metode Penelitian Kuantitatif, Kualitatif, dan R\&D. Bandung : Alfabeta, CV.

[18] Astutik. (2010). Teori Metode Lovaas / Applied Behavior Analysis ( ABA). 